\title{
PENGARUH PEMBERIAN EKSTRAK BAWANG PUTIH (Allium sativum) PADA BERBAGAI DOSIS TERHADAP DAYA TETAS TELUR IKAN TAWES (Puntius javanicus)
}

\section{THE EFFECT OF GARLIC (Allium sativum) EXTRACT WITH DIFFERENT DOSAGE ON THE HATCHABILITY OF TAWES FISH (Puntius javanicus) EGGS}

\author{
Fitria Rahmayanti ${ }^{1 *}$, Farah Diana ${ }^{1}$, Silviana Rosa ${ }^{2}$ \\ ${ }^{1}$ Jurusan Akuakultur, Fakultas Perikanan dan Ilmu Kelautan Universitas Teuku Umar \\ ${ }^{2}$ Jurusan Perikanan, Fakultas Perikanan dan Ilmu Kelautan Universitas Teuku Umar \\ *Korespondensi: rea_syakurah@yahoo.co.id
}

\begin{abstract}
ABSTRAK
Penelitian ini bertujuan untuk mengetahui efektivitas dan pengaruh pemberian ektrak bawang putih (Allium sativum) sebagai anti jamur pada telur ikan tawes (Puntius javanicus). Penelitian ini dilaksanakan pada bulan Juli Tahun 2015. Penelitian ini bersifat eksperimen dengan menggunakan Rancangan Acak Lengkap (RAL) pada 4 perlakuan dan 3 ulangan. Perlakuan yang digunakan adalah dengan penambahan ekstrak bawang putih pada beberapa dosis yaitu P0 (tanpa perlakuan), P1 (1 ml/L), P2 (2 ml/L), P3 (3 ml/L). Selama penelitian dilakukan pengukuran parameter kualitas air dan Daya Tetas telur ikan tawes. Hasil penelitian menunjukkan bahwa ekstrak bawang putih (Allium sativum) berpengaruh sangat signifikan terhadap daya tetas telur ikan tawes (Puntius javanicus). Daya tetas tertinggi dihasilkan pada perlakuan P3 $(3 \mathrm{ml} / \mathrm{L})$ sebanyak $82,3 \%$ dan dilanjutkan dengan perlakuan P2 (2 ml/L) sebanyak 73,6\%, P1 (1 ml/L) sebanyak 67,3\% serta P0 (tanpa perlakuan) sebanyak 51\%. Parameter kualitas air yang didapatkan selama penelitian sebelum pencampuran larutan ekstrak bawang putih rata-rata suhu 28, $\mathrm{pH} 7.0, \mathrm{DO} 3.7$ dan ratarata kualitas air setelah pencampuran larutan ektrak bawang putih suhu 28, $\mathrm{pH} 7.0$, dan DO 3.8 ppm.
\end{abstract}

Kata Kunci: Ekstrak bawang putih, ikan tawes, daya tetas, telur ikan

\begin{abstract}
This research was conducted in order to determine the effectivity of garlic extract (Allium sativum) as antifungal on tawes eggs (Puntius javanicus) and to know the effect of garlic extract (Allium sativum) as antifungal on tawes eggs (Puntius javanicus). This research was conducted in July 2015. This reasearch used experimental designs and Completely Randomized Design method with four treatments and three replications. The treatment was applied by adding garlic extract with P0: without treatment, P1: $1 \mathrm{ml} / \mathrm{L}, \mathrm{P} 2: 2 \mathrm{ml} / \mathrm{L}$ and $\mathrm{P} 3: 3 \mathrm{ml} / \mathrm{L}$. Water quality parameters and Hatching Rate (HR) are calculated during this reasearch. The result showed that garlic extract (Allium sativum) effect the hatchability of tawes fish eggs with high significance. The higest hatching rate to the lowet were in treatment P3 $(3 \mathrm{ml} / \mathrm{l})$, treatment P2 $(2 \mathrm{ml} / \mathrm{l})$, treatment P1 $(1 \mathrm{ml} / \mathrm{l})$ and treatment P0 (as the control) with the hatching rate values were 82,3\%, 73,6\%,67,3\% and $51 \%$, respectively. The water quality parameters during the research were temperature $28^{\circ} \mathrm{C}, \mathrm{pH}$ 7.0 and DO $3.8 \mathrm{ppm}$.
\end{abstract}

Keywords: Garlic extract, tawes fish, hatchability, fish eggs

*Fakultas Perikanan dan Ilmu Kelautan, Universitas Teuku Umar Korespondensi : Jurusan Akuakultur, Fakultas Perikanan dan Ilmu Kelautan, Universitas Teuku Umar, Kampus UTU Meulaboh, Alue Peunyareng 23615, Telp: +62 85297805010, email: rea_syakurah@yahoo.co.id 


\section{PENDAHULUAN}

Ikan tawes merupakan salah satu jenis ikan budidaya yang penting khususnya di Indonesia. Budidaya ikan tawes pada umumnya tidak terlepas dari resiko biologis terutama yang disebabkan oleh adanya gangguan penyakit dan infeksi jamur. Sugianti (2009) menjelaskan bahwa jamur yang biasa menyerang telur ikan tawes (Puntius javanicus) adalah Saprolegnia sp. Jamur dapat menyerang telur dan berkembangbiak di dalamnya karena terdapat luka akibat serangan bakteri. Jika telur ikan tawes dibiarkan menetas di kolam pemijahan, maka akan mudah terserang oleh hama penyakit. Begitu juga dengan pemindahan telur dari kolam ke wadah penetasan, terdapat kemungkinan ikut terbawanya parasit bersama dengan telur. Parasit yang berupa bakteri akan menginfeksi telur sehingga telur menjadi rusak dan kemudian diinfeksi oleh jamur.

Oleh karena itu, perlu dilakukan tindakan pencegahan dan pengobatan agar telur tawes (Puntius javanicus) yang ditetaskan, terbebas dari serangan penyakit. Tindakan pencegahan dan pengobatan terhadap serangan jamur Saprolegnia sp. sering menggunakan senyawa sintetik yang telah terbukti efektifitasnya sebagai anti jamur sehingga kualitas telur dapat meningkat. Namun dipihak lain, pemakaian bahan kimia dan anti biotik secara terus-menerus dengan konsentrasi yang tidak tepat dapat menimbulkan masalah baru yaitu meningkatkan resistensi parasit terhadap senyawa sintetik tersebut.

Salah satu tanaman tradisional yang berpotensi dapat mengobati penyakit akibat jamur adalah bawang putih (Allium sativum). Bawang putih diketahui memiliki kandungan zat yang bersifat anti jamur. Menurut Pitriono (2014), bawang putih mengandung minyak atsiri yang sangat mudah menguap di udara bebas. Minyak atsiri dari bawang putih diduga mempunyai kemampuan sebagai antibakteri dan antiseptik. Selain itu Yongki (2009) mengunngkapkan bahwa Bawang putih juga terbukti dapat menghambat pertumbuhan dan respirasi fungsi patogenik. Daya antimikroba tinggi yang dimiliki bawang putih dan bawang bombay dikarenakan kandungan alisin dan senyawa sulfida lain yang terkandung dalam minyak atsiri bawang putih dan bawang bombay. Oleh sebab itu, penulis merasa tertarik untuk melakukan penelitian mengenai pengaruh pemberian ekstrak bawang putih sebagai anti jamur pada telur ikan tawes.

Adapun tujuan dari penelitian ini adalah untuk mengetahui efektifitas ekstrak bawang putih sebagai anti jamur pada telur ikan tawes dan mengetahui pengaruh pemberian ekstrak bawang putih sebagai anti jamur pada telur ikan tawes pada berbagai dosis. Hasil penelitian ini diharapkan dapat menjadi informasi adalah untuk meminimalkan infeksi jamur pada telur ikan tawes sehingga meningkatkan produksi benih ikan tawes.

\section{METODE PENELITIAN}

Penelitian ini telah dilaksanakan pada bulan Juli Tahun 2015. Alat yang digunakan pada penelitian ini adalah wadah plastik, $\mathrm{pH}$ indikator, DO meter, termomete, aerator, saringan halus (kertas saring) dan kamera. Sedangkan bahan yang digunakan adalah telur ikan tawes, bawang putih, air dan aquades. Penelitian ini bersifat eksperimen dengan menggunakan Rancangan Acak Lengkap (RAL) pada 4 perlakuan dan 3 ulangan. Sebagai perlakuan dilakukan penambahan ekstrak bawang putih dengan dosis yaitu $\mathrm{P} 0$ (tanpa perlakuan), P1 (1 ml/L), P2 (2 ml/L), dan P3 (3 ml/L).

\section{Prosedur Penelitian}

Pelaksanaan penelitian ini meliputi persiapan wadah penelitian, persiapan telur ikan tawes, persiapan ekstrak bawang putih, dan pengamatan.

g. Persiapan wadah penelitian dilakukan dengan membersihkan wadah plastik kapasitas $10 \mathrm{~L}$ kemudian diisi dengan air sebanyak $8 \mathrm{~L}$.

h. Persiapan telur ikan tawes dilakukan dengan memasukkan telur ikan tawes sebanyak 100 butir untuk setiap wadahnya.

i. Persiapan ekstrak bawang putih dilakukan dengan merebus bawang putih lalu dihaluskan dengan cara diblender. Setelah dingin baru dilakukan penambahan aquades sucukupnya kemudian disaring dengan menggunakan kertas saring. Setelah itu ekstrak bawang putih dimasukkan ke dalam wadah uji sesuai dosis masing-masing perlakuan untuk dilakukan perendaman selama 30 menit. Kemudian telur uji dimasukkan kedalam wadah penetasan. Selama 
penelitian, dilakukan perhitungan telur yang menetas dan pengukuran paramater kualitas air.

\section{Parameter Uji}

Pada penelitian ini dilakukan pengamatan dan perhitungan jumlah telur ikan tawes yang menetas kemudian dilakukan perhitungan daya tetas dengan rumus sebagai berikut:

$$
\frac{\text { JumlahTelur Yang Menetas(butir) }}{\text { JumlahTelur yangdiinkubasi(butir) }} \times 100 \%
$$

Selain itu juga dilakukan pengukuran parameter kualitas air berupa temperatur air, konsentrasi oksigen terlarut dan $\mathrm{pH}$ air.

\section{HASIL DAN PEMBAHASAN}

Dari hasil penelitian yang telah dilakukan terhadap daya tetas telur ikan tawes (Puntius javanicus) pada perendaman dengan larutan ekstrak bawang putih (Allium sativum) didapatkan hasil tingkat daya tetas telur yaitu P0 (kontrol) daya tetas rata-rata 51 $\%$, P1 (1 ml) dengan daya tetas rata-rata 67,3 $\%$, P2 (2 ml) daya tetas rata-rata $73,6 \%$ dan P3 daya tetas $(3 \mathrm{ml}) 82,3 \%$. Persentase daya tetas telur ikan tawes yang menetas dapat dilihat pada gambar 1.

Pada setiap perlakuan daya tetas telur ikan tawes berbeda tinggkat penetasannya dengan daya tetas tertinggi dihasilkan oleh perlakuan P3 (dosis $3 \mathrm{ml} / \mathrm{L}$ ) adalah $82,3 \%$, sedangkan pada perlakuan terendah terdapat pada P0 (kontrol) sebanyak 51\%, P1 (dosis 1 $\mathrm{ml} / \mathrm{L}$ ) sebanyak $67,3 \%$, dan P2 (dosis $2 \mathrm{ml} / \mathrm{L}$ ) sebanyak $73,6 \%$. Hal ini menunjukkan bahwa perendaman telur ikan tawes dalam larutan ekstrak bawang putih berpengaruh pada penetasan telur ikan tawes dan menghambat pertumbuhan jamur yang menyerang pada telur ikan tawes.

Dari hasil analisis sidik ragam (ANOVA) yang telah dilakukan selama penelitian terbukti bahwa nilai $\mathrm{F}_{\mathrm{h}}>\mathrm{F}_{\mathrm{t}}$, yang berati bahwa pemberian ekstrak bawang putih berpengaruh sangat nyata terhadap terhadap daya tetas telur ikan tawes. Menurut Cavalito dalam Wibowo (2007) mengemukakan bahwa allisin dikenal mempunyai daya antibakteri yang kuat. Allisin yang terkandung dalam ekstrak bawang putih bekerja aktif mencegah serangan jamur Saprolegnia sp. Saprolegnia sp. tidak dapat menembus chorion telur untuk mengambil zat-zat makanan yang ada di dalamnya sehingga meningkatkan daya tetas telur ikan tawes.

Sementara itu, zat yang diduga berperan memberi aroma bawang putih yang khas adalah alisin karena alisin mengandung sulfur dengan struktur tidak jenuh di dalam beberapa detik saja terurai menjadi senyawa dialilsulfida. Di dalam tubuh, alisin merusak protein bakteri penyakit, sehingga bakteri penyakit tersebut mati (Pitriono, 2014). Menurut Triakoso (1999), senyawa allisin dan dialil sulfida memiliki sifat bakterisida dan menghambat perkembangan jamur maupun mikroba. Selain itu pula, penggunaan dosis antifungi atau antibakteri yang dikombinasikan dengan perendaman yang tepat akan meningkatkan derajat penetasan telur ikan tawes dan tidak merusak telur.

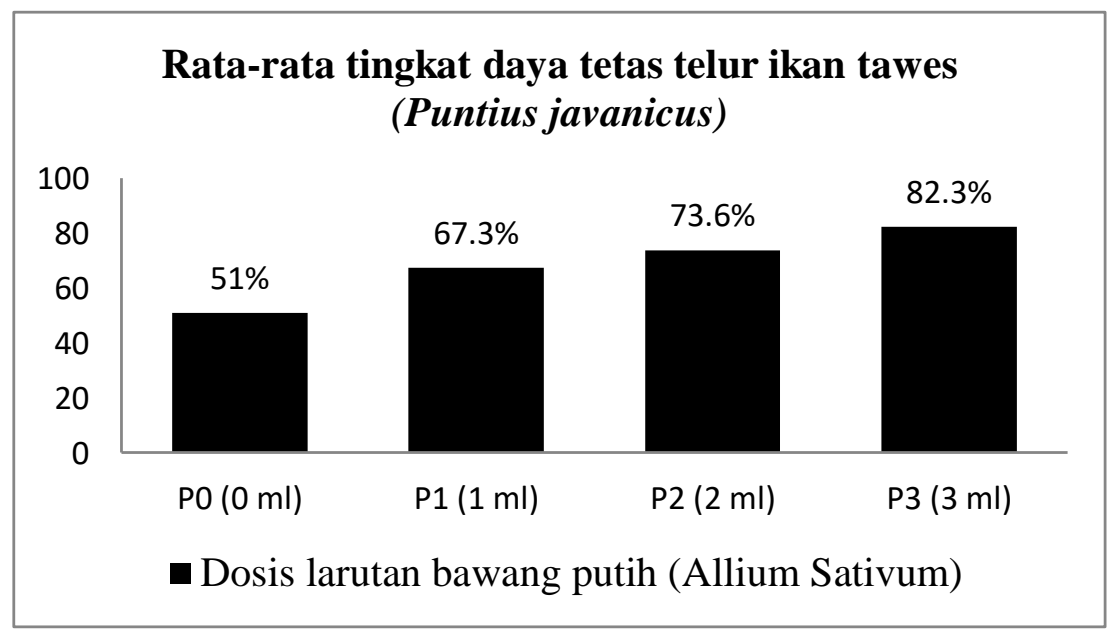

Gambar 1. Tingkat daya tetas telur ikan tawes yang direndam 
Penentuan dosis yang paling tepat untuk mencegah pertumbuhan jamur pada telur ikan tawes sangat penting dilakukan untuk mendukung keberhasilan pembenihan. Menurut Sugiarto dalam Martini (2005), pemakaian zat anti mikroba pada konsentrasi normal bersifat menghambat pertumbuhan mikroba tetapi pada konsentrasi yang lebih tinggi allisin dapat merusak jaringan sel. Menurut Martini (2005) menyatakan bahwa telur yang tidak direndam dengan ekstrak bawang putih hanya mengandalkan kekerasan chorion untuk menahan serangan Saprolegnia sp. Saprolegnia sp. dapat melemahkan kekakuan chorion menjadi berkerut kemudian mati.

Selama penelitian berlangsung, pengukuran parameter kualitas air penting dilakukan sebagai kontrol, agar parameter air sesuai untuk kegiatan pembenihan. Adapun parameter kualitas air yang terukur selama penelitian ini berlangsung dapat dilihat pada Tabel 1.

Aspek kualitas air merupakan salah satu parameter yang sangat penting dalam kegiatan budidaya perairan. Nilai kualitas air selama penelitian menunjukkan bahwa parameter ini masih dalam batas kelayakan untuk kehidupan ikan tawes. Hasil pengukuran suhu selama penelitian ini $28^{\circ} \mathrm{C}$. Menurut Santoso (1996) dalam Siti et al. (2009) menyatakan kisaran kelayakan temperatur air bagi ikan tawes adalah $14-28^{\circ} \mathrm{C}$. Suhu mempengaruhi aktivitas metabolisme organisme, karena itu penyebaran organisme baik dilautan maupun diperairan air tawar dibatasi oleh suhu perairan tersebut. Secara umum laju pertumbuhan meningkatkan sejalan dengan kenaikan suhu dapat menekan kehidupan hewan budidaya bahkan menyebebkan kematian bila peningkatan suhu eksrim (Gufran, 2007).

Tabel 1. Kualitas air selama penelitian

\begin{tabular}{cccc}
\hline No & Parameter & $\begin{array}{c}\text { Selama } \\
\text { Penelitian }\end{array}$ & $\begin{array}{c}\text { Suhu } \\
\text { Optimal }\end{array}$ \\
\hline 1 & Suhu & $28{ }^{\circ} \mathrm{C}$ & $24-32^{\circ} \mathrm{C}$ \\
\hline 2 & pH & 7 & $6.5-7$ \\
\hline 3 & DO & 3.8 & $3.5-4.0$ \\
\hline
\end{tabular}

\section{KESIMPULAN}

Perendaman telur ikan tawes dengan larutan ekstrak bawang putih pada perlakuan (P3) dengan dosis $3 \mathrm{ml}$ memberi pengaruh terhadap daya tetas telur ikan tawes. Larutan ekstrak bawang putih mengandung berbagai macam zat aktif diantaranya zat alisin dan minyak atsiri yang merupakan komponen utama yang berkhasiat melindungi telur dari serangan jamur dan dapat menekan perkembangan jamur hingga $82,3 \%$.

\section{DAFTAR PUSTAKA}

Amri dan Khairuman. 2008. Buku Pintar Budidaya 15 Ikan Konsumsi. . Jakarta: Agromedia

Alifuddin M. 1996. Penyakit Mikotik Ikan. Laboratorium Kesehatan Ika. Bogor: Fakultas Perikanan Institut Pertanian Bogor.

Bachtiar Y. 2004. Budidaya Ikan Koi Kolam Perkarangan. Jakarta: Penebar Swadaya.

Dewi, U. 2001. Pengaruh Pemupukan Lanjutan Terhadap Sintasan laju Pertumbuhan Benih Ikan Mas (Ciprinus Carpio) Pada pendederan Pertama: IPB. Bogor.

Handoyo B. 2007. Produksi Ikan Hias. Balai Budidaya Air Tawar Jambi. Jakarta: Direktorat Jenderal Perikanan Budidaya Departemen Kelautan Dan Perikanan.

Kottelat MJA, Whitten NS, Kartikasari and Wirjoatmodjo S, 1993. Freshwater Fishes of Western Indonesia and Sulawesi. Canada: Dalhousie University.

Martini, A. 2005 .EfektivitasEkstrakBawang Putih untuk Mencegah Serangan Saprolegnia sp. Pada Telur Ikan Gurami. Karya Ilmiah. Bandung: Fakultas Pertanian Jurusan Perikanan Universitas Padjajaran.

Nelson SJ. 2006. Fishes of the World.Canada: Wiley. .

Pitriono. 2014. Pengunaan ekstrak allium sativum untuk perawatan luka gigitan ular kobra [Skripsi]. Surakarta: Keperawatan. Stikes Kusuma Hasada.

Priskila M. 2008. Pengaruh Pemberian Ekstrak Bawang Putih (Allium Sativum Linn.) Terhadap Penurunan Rasio Antara Kolesterol Total Dengan 
Kolesterol Hdl Pada Tikus Putih (Rattus Norvegicus) Yang Hiperkolesterolemik [Skripsi]. Surakarta: Fakultas Kedokteran Universitas Sebelas Maret.

Syamsiah T. 2003. Khasiat dan Manfaat Bawang Putih Raja Antibiotik Alam. Jakarta: Agromedia Pustaka.

Safithri. 2004. Aktifitas Antibakteri Bawang Putih (Alium Sativum) Terhadap Bakteri Mastitis Subklinis secara In vitro dan In vivo pada Ambing Tikus Putih (Rattus Novergicus) [Tesis]. Bogor: Program Pascasarjana Institut Pertanian Bogor.

Siti R dan Astri DS. 2009. Pertumbuhan dan Survival Rate Ikan Mas (Cyprinus Carpio) pada

Berbagai Konsentrasi Pestisida. Semarang: Universitas Diponerogo.

Susanto H. 2003. Budidaya Ikan Koi Secara Intensif. Jakarta: Agromedia Pustaka.

Triakoso. 1999. Manfaat Bawang Putih (Allium sativum) Sebagai Makanan Tambahan Dalam Upaya Mempertahankan Produktivitas Ayam Pedaging. Surabaya: Karya Ilmiah Fakultas PeternakanUniversitas Airlangga.

Wibowo S. 2007. Budidaya Bawang Putih, Bawang Merah, Bawang Bombay. Jakarata: Penebar Swadaya. 